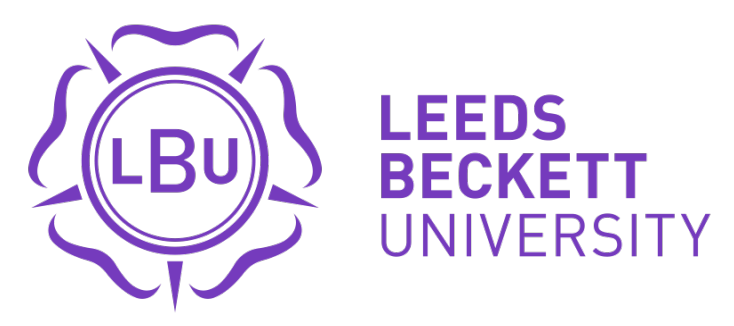

Citation:

Font, $\mathrm{X}$ and Walmsley, A and Cogotti, S and McCombes, L and Häusler, N (2012) Corporate social responsibility: The disclosure-performance gap. Tourism Management, 33 (6). 1544 - 1553. ISSN 0261-5177 DOI: https://doi.org/10.1016/j.tourman.2012.02.012

Link to Leeds Beckett Repository record:

https://eprints.leedsbeckett.ac.uk/id/eprint/275/

Document Version:

Article (Updated Version)

The aim of the Leeds Beckett Repository is to provide open access to our research, as required by funder policies and permitted by publishers and copyright law.

The Leeds Beckett repository holds a wide range of publications, each of which has been checked for copyright and the relevant embargo period has been applied by the Research Services team.

We operate on a standard take-down policy. If you are the author or publisher of an output and you would like it removed from the repository, please contact us and we will investigate on a case-by-case basis.

Each thesis in the repository has been cleared where necessary by the author for third party copyright. If you would like a thesis to be removed from the repository or believe there is an issue with copyright, please contact us on openaccess@leedsbeckett.ac.uk and we will investigate on a case-by-case basis. 


\title{
Corporate social responsibility: the disclosure-performance gap
}

Font, Walmsley, Cogotti, McCombes and Häusler

\begin{abstract}
:
As increased stakeholder pressure requires companies to be transparent about their CSR practices, it is essential to know how reliable corporate disclosure mechanisms are, testing the gap between corporate social responsibility claims and actual practice. This study benchmarks corporate social responsibility policies and practices of ten international hotel groups of particular importance to the European leisure market. We found that corporate systems are not necessarily reflective of actual operations, environmental performance is ecosavings driven, labour policies aim to comply with local legislation, socio-economic policies are inward looking with little acceptance of impacts on the destination, and customer engagement is limited. Generally larger hotel groups have more comprehensive policies but also greater gaps in implementation, while the smaller hotel groups focus only on environmental management and deliver what they promised. As the first survey of its kind in tourism, both the methodology and the findings have implications for further research.
\end{abstract}

Keywords: greenwashing, reporting, sustainability, governance.

Acknowledgements: We would like to thank International Consumer Research and Testing for financing this study, on behalf of their members that published the results in: Austria (Verein Fur Konsumenteninformation), Belgium (Association Belge des consommateurs Test-Achats), Denmark (Taenk/Forbrugerraadet), Finland (Kuluttajavirasto), Italy (Euroconsumers Servizi SRL), Portugal (DECO-Proteste Editores LDA), Spain (OCUOrganización de Consumidores y Usuarios Ediciones SA) and Sweden (Rad \& Ron). The research was project managed by Amaya Apesteguía.

\section{Introduction}

Despite Friedman's (1970) view on the limitations of the responsibility of business, the notion that businesses have responsibilities beyond providing economic returns to the owners of capital is, judging by the profusion of claims by corporations as to their Corporate Social Responsibility (CSR) activities (KPMG International, 2008), as well as the discourse around CSR in the literature (Carroll, 1999), widely accepted. Nonetheless, the meaning of CSR is contested although to aver, as Frankental (2001) does, that because CSR is a vague and intangible term it is effectively without meaning is far-fetched. The foundation of CSR is the acknowledgement that businesses have responsibilities to society that go beyond shareholder wealth maximisation (e.g. Henderson, 2007). This belief is widely held, and hence a degree of shared understanding and common meaning exists. 
Some, such as Bendell (2004) and Hess (2008), have argued that the nature of global business with its shift in power from the state to supranational corporations has ushered in an era of increased corporate accountability, a view further expedited through the multitude of cases of corporate fraud and accounting irregularities at the turn of the millennium (e.g. Enron and WorldCom). Certainly, the past decade has seen growing pressure on corporations from individual consumers, consumer groups, NGOs and governments to take stock of their noncommercial impact on society. However, businesses' acknowledgement of the CSR agenda does not necessarily result in more responsible behaviour (Hess, 2008, has for example questioned to what extent social reporting leads to improved CSR performance, or whether conversely it is just a method to avoid additional introduction of regulation) ${ }^{7}$. Furthermore, it is not enough to be responsible, corporations realise that their CSR activities also need to be reported, and that transparency in reporting is crucial if companies are to be held to account for their actions.

This study addresses these issues in relation to the tourism industry. Specifically, the study set out to investigate to what extent ten global hotel chains' CSR claims were supported by evidence, or whether they were, at worst, mere rhetoric. In other words, this study looks at the potential disclosure-performance gap. Publicly available information was scrutinised, the hotel chains were given the opportunity to comment on our initial analyses and site visits were subsequently conducted to seek corroborating evidence for the companies' claims. The study provides a unique analysis of CSR behaviour and reporting in the tourism industry at a time when interest in businesses' impacts on society is only likely to increase.

\section{Literature review}

Reasons for engagement in CSR activities are varied although often it simply comes down to seeking competitive advantage, not because of some fundamental moral commitment to doing what is right, although Hess (2008) does argues that this should be the ultimate goal of CSR. The use of sustainability language and posturing helps the corporation create an external, and to a large extent also internal, image of what the company wants to be seen asin the case of CSR, a caring, nurturing firm. This can be far from the mundane efficiency demands of "getting things done" which puts CSR on the backburner. Nonetheless, while an argument can be made that the justification for undertaking CSR does not matter as it is the ends that count, it is not unheard of that companies may portray themselves as being responsible while they in no way are. Lyon and Maxwell (2011:9) define greenwash as "selective disclosure of positive information about a company's environmental or social performance, without full disclosure of negative information on these dimensions, so as to create an overly positive corporate image". It might more simply be stated that at the heart of greenwashing lie claims that lack substance, the portrayal of something that you are not, a deliberate attempt to mislead, or, as Laufer (2003:253) suggests ‘corporate disinformation'. Placed in the language of CSR reporting we might call this a disclosure-performance gap.

If companies are to be held to account for their actions, then transparency in reporting is clearly crucial. However, being transparent does not necessarily mean revealing everything as this can be counterproductive to the communication of the key message (Bebbington, Gray 
and Owen, 1999). Consequently, companies must decide how much information to disclose, balancing different stakeholders' needs whereby it is sometimes necessary to disclose information that puts the company in a bad light. The ample room for manoeuvre in identifying significant impacts and prioritising them has been partly blamed for the little significance behind achieving formal public endorsement for CSR disclosure (Boiral, 2007). CSR reporting clearly entails more than relating only positive stories (Kaptein, 2007).

While there is much agreement on the need to measure and report on CSR activities, how it should be measured is less clear and remains a challenging task (Morimoto, Ash and Hope, 2005). This is not to say that there is a dearth of literature on the subject of measuring CSR as Wood's (2010) recent review established. Alas, comparability of CSR reports stumbles over the issue of non-conformity in reporting. This issue has been alleviated to an extent with the emergence of standards such as those provided by the Global Reporting Initiative (GRI), the ICC Business Charter for Sustainable Development and specifically in relation to environmental management International Standards Organization's ISO 14001 guidelines and the European Union's Eco-Management and Audit Scheme (EMAS). However, even where companies use these standards and guidelines this does not prevent questionable reporting taking place (Bonilla-Priego and Avilés-Palacios, 2008). Boiral (2007), for example, shows how the systems behind ISO14001 certification weren’t a genuine management tool, but a mechanism to promote the company's image- similar to many Spanish hotels certified under EMAS (Bonilla-Priego, Najera and Font, 2011). Boiral (2007) continues by arguing that certification is often seen as a cumbersome, time and resource consuming system that cannot be justified in times of recession. Certainly, that it cannot necessarily be justified for the improvements achieved in environmental performance. He reports that environmental procedures, central to the management system, were far from being implemented- except prior audits, when non conformities were hurriedly reduced as a tidy up job. Hawkins and Bohdanowicz (2011) analyse a range of practices in international hotel groups that show the gap between what could be achieved and where most firms are at, despite a clear business case for action.

There is little information in tourism that assesses the state of CSR reporting. It has been suggested that industries with a higher pollution propensity are more likely to provide discretionary disclosure (Clarkson, Li, Richardson and Vasvari, 2008). Within a single industry, firm size (Lang and Lundholm, 1993;Morhardt, 2010), reliance on stock markets for investment (Chatterji, Levine and Toffel, 2009) and equipment age (Healy and Palepu, 2001) are determinants of voluntary disclosure. We could therefore expect hotels, being relatively low pollution, to be in the early stages of reporting, and for larger hotel groups with publicly traded shares to feel greater pressure to report, those with newer buildings (with newer cleaner technologies) to have a higher environmental performance and therefore willingness to report.

Similar to our study, Henderson (2007) attempted to research hotel chains' CSR practices, albeit restricted to Phuket in Thailand after the Tsunami of 2004. However, only two hotels responded to her request for information forcing a reliance on publicly available information. Her findings indicated that the bulk of CSR activity was related to issues that also promoted 
the destination image, i.e. where the CSR activity was not solely altruistic in intent. She also acknowledges that to some companies CSR activities are more likely to be engaged with in trouble-free times of growing profits (Henderson, 2007).

Bohdanowicz and Zientara (2009) also undertook an investigation into hotels' CSR reporting. Again, the emphasis was on data available through websites. Their results were somewhat ambiguous, with some hotels performing well (e.g. the existence of CSR officers and a CSR policy) and others barely doing anything at all. A further study that sought to understand CSR reporting (Holcomb, Upchurch and Okumus, 2007) came to some conclusions that contrast with those of Bohdanowicz and Zientara (2009). The results of Holcomb et al.'s (2007) study were in fact not that different, just the assessment of the hotel industry's engagement with CSR differed. While they agree that CSR is assuming a greater importance for hotel chains, they also argue that the message of the importance of CSR has yet to hit home. Hilton and Accor came in for praise in relation to their CSR reporting, and in particular Hilton was highlighted as being the only hotel chain that permitted an external audit of its CSR reporting. Overall, Holcomb et al. (2007) reiterate that little research is available regarding CSR in tourism and that "more in-depth studies regarding the reporting of CSR issues" is required. Our study addresses this issue.

\section{Methodology}

This study was commissioned by the International Consumer Research and Testing organisation on behalf of eight European consumer associations (see acknowledgements). These consumer associations pull together resources to commission research on individual industries identified as of interest to their members. The recognition by the corporations of these consumer associations and the risk of alienating their members ensured participation from the majority of hotel chains investigated here.

The funding organisation's preference was to select hotel groups with a good offer on leisure hotels, with a strong presence in Europe or of importance to European leisure travellers. The list of hotel groups was devised in consultation with European tour operators to assess the importance to mainstream holidaymakers. The final list covered ten hotel groups, responsible for 64 hotel brands (see table 1). Spanish-owned hotels are strongly represented (Sol Meliá, RIU, Barceló, Iberostar). This is due to their importance in both the Spanish and the Caribbean/Mexican destinations as suggested by the tour operators interviewed for this study. The list did not include Wyndham Hotels and Choice Hotels, the two largest groups worldwide in terms of bed spaces, due to their primary US focus. In the case of Carlson, separate CSR documentation and questionnaires were received for the Americas, Europe, and Asia-Pacific as CSR aspects are operated independently.

Table 1. Hotel groups and brands

\begin{tabular}{|l|l}
\hline ACCOR & Sofitel, Pullman, Novotel, Mercure, Adagio, Suite Novotel, Ibis, \\
INTERNATIONAL & All Seasons, Etap Hotel, Hotel F1, Motel 6, Studio 6
\end{tabular}




\begin{tabular}{|l|l|}
\hline $\begin{array}{l}\text { BARCELO HOTELS \& } \\
\text { RESORTS }\end{array}$ & Barceló \\
\hline CARLSON GROUP & Radisson, Country Inns\&Suites, Park Inn, Park plaza, Regent \\
\hline HILTON & $\begin{array}{l}\text { Hilton, Hilton Garde Inn, Homewood suites Hilton, Hilton Grand } \\
\text { vacations, Waldorf Astoria, Conrad, Double Tree, Embassy Suites } \\
\text { Hotels, Hampton, Home2 suites by Hilton }\end{array}$ \\
\hline $\begin{array}{l}\text { IBEROSTAR } \\
\text { HOTELS GROUP }\end{array}$ & $\begin{array}{l}\text { Iberostar } \\
\text { Coliday Inn Express, Hotel Indigo, Staybridge Suites, }\end{array}$ \\
\hline $\begin{array}{l}\text { MARRIOTT } \\
\text { INTERNATIONAL }\end{array}$ & $\begin{array}{l}\text { Marriott Hotels \& Resorts, JW Marriott, Renaissance Hotels, } \\
\text { Edition Hotels, Autograph collection, Courtyard, Residence Inn, } \\
\text { Fairfield Inn \& Suites, TownePlace Suites, SpringHill Suites , The } \\
\text { Ritz-Carlton }\end{array}$ \\
\hline $\begin{array}{l}\text { RIUU HOTELS } \\
\text { HOTELS\&RESORTS }\end{array}$ & $\begin{array}{l}\text { Re Meriu } \\
\text { Sheraton, Element, St. Regis, W Hotels }\end{array}$ \\
\hline SOL MELIÁ & $\begin{array}{l}\text { Sol Hoteles, Meliá, Tryp, Grand Meliá, Paradisus Resorts, Me, } \\
\text { Innside by Meliá }\end{array}$ \\
\hline
\end{tabular}

A wide range of CSR disclosure indices have been developed (Morhardt, 2010; Unerman, 2000), with Wiseman's study (1982) still being central to many. Most published CSR content analyses have collected descriptive data. Occasionally indices have been generated but ranking individual companies within a sector has been largely avoided. This is understandable given the complexity of indicators as well as their inherent subjectivity (Morhardt, 2010). Our index was developed through an analysis of the literature, especially drawing on international guidelines and certification programmes for sustainability in tourism, the Global Reporting Initiative and preliminary content analysis of CSR reports from tourism and hospitality firms. The preliminary list was then evaluated by the CSR, labour, environmental management and customer rights' staff at the different consumer associations commissioning this study, and compared against previous studies conducted by them in other sectors. It was decided to drop a number of criteria after further analysis of CSR reports from the ten selected hotel groups. The reason for non-inclusion included the inability of the indicator to differentiate satisfactorily between the firms, or the absence of realistic means of collecting data against the criteria. The attempt of calculating the percentage of hotels in each group that meet company policy was dropped due to hotel groups not collecting systematically such data for all indicators. Accessibility for customers with disabilities was 
reduced to access for wheelchair users due to the limited practices in most hotels, equally the analysis of dietary needs focused on celiac and dropped other food intolerances as well as hallal and kosher food.

In our study, 39 indicators provided evidence for 13 criteria on six different themes with weightings as follows: Corporate Policies (10\% of the weighting), Labour Issues (20\%), Socioeconomic Issues (20\%), Environmental Issues (25\%), Customer Engagement (15\%), and Transparency (10\%). These weightings were discussed and agreed with the consumer associations. To illustrate, the theme Corporate Policies covered the following criteria: Endorsement of international key conventions, Resources for CSR, Staff training program on sustainable issues, CSR management systems, and Independent certification of sustainability practices, each with a number of indicators, with their own weightings. As an example, the criteria Policy on Social Impacts at the Destination was informed by three indicators 1) Monitor any loss of access to natural resource by local communities and formally engage to remediate it, 2) No sexual exploitation of children in the hotel properties or by customers staying in their properties is a formal engagement of the company, and 3) Support to philanthropic or community projects.

The content analysis of the collected material focused on the type of themes covered and the quality/evidence of the claims being made (Clarkson, et al., 2008;Morhardt, 2010). Our scoring of sustainability performance follows the principles in Wiseman's seminal paper, without the blanket trust on quantitative scores. Wiseman scored ' 3 ' for quantitative disclosure, ' 2 ' for non-quantitative disclosure, ' 1 ' for mentioning in general terms, ' 0 ' for no disclosure. The score definitions in our study were tailored to each indicator and were the result of benchmarking content analysis (see table 2 for an example) from 0 to 5. Our study does not differentiate between hard and soft disclosure items (all items would be considered hard according to Clarkson's definition), but the level of strength/reliability of the disclosed evidence is included in the item scoring.

Table 2. CSR themes and weighting

\begin{tabular}{|l|l|}
\hline Theme & Weighting \\
\hline Corporate policies & $10 \%$ \\
\hline Labour issues & $20 \%$ \\
\hline Socio-economic issues & $20 \%$ \\
\hline Environmental issues & $25 \%$ \\
\hline Customer engagement & $15 \%$ \\
\hline Transparency & $10 \%$ \\
\hline
\end{tabular}


The emphasis of this study was in particular to evaluate corporate policies and their implementation in practice. Staff responsible for CSR in each hotel group were identified and approached in June 2010 with a questionnaire to measure the reporting of CSR policies against pre-defined criteria. The research team conducted a two month review of all public documents found in these hotel groups' websites (as in Clarkson, et al., 2008;Holcomb, et al., 2007). Publicly available information not produced by the hotel groups themselves was not used in the content analysis unless it could be verified against internal data (e.g. lists of signatories of the UN Global Compact, ECPAT, OECD Guidelines for Multinational Enterprises). All data were entered into an Excel spreadsheet with links to the original documents to keep trails of evidence. A further column was used to transcribe the results of the hotel groups' questionnaire results against the same indicators, including data from internal confidential documents for which confidentiality agreements were signed when required. Both sets of data were submitted to the hotel groups in August- the data were analysed against score definitions, but neither the scores nor the definitions were sent to the company- the purpose was not to see if they agreed on the scoring mechanism, but whether the data themselves that formed the basis of the evaluation were correct. Each hotel group received only their own data set.

A further piece of the assessment jigsaw involved visits to a sample of hotels within each hotel chain. These were arranged for September 2010. Their purpose was to verify the extent to which CSR policies were being applied in practice in individual establishments. All hotel groups were visited in at least two countries (apart from RIU who declined to participate). Six visits were performed in Thailand, eight in Cancun and eight in Southern Europe (three in Nice and five in Mallorca). Hotel visits took on average eight hours, and were primarily conducted in the local language. In Thailand, visits involved at least one night's stay, usually more, while in the remaining destinations the auditor stayed in the same audited hotel for the entire period of audits due to limited availability in high season. All stays were paid for by the research team and no gifts were accepted to avoid conflicts of interest. Visits included interviews with management and staff, walk through assessments, collection of documentary evidence as well as a review of minutes of meetings and policy documents. The emphasis of these hotel visits was an assessment of compliance with group CSR policies- sustainability practices individual to a specific site but outside group policy were noted but not used for scoring purposes.

In October visit results were sent to the companies together with clarification questions, mostly where inconsistencies between the policy and the performance were identified. The calculations for each indicator were then based on a scoring of the results on a 5-item scale, and the validation of the visits in the field from ' 0 '-contradicted to ' 1 '-fully validated with 0.5 and 0.75 for partial validations. Not accepting a visit to a hotel equated to a 0 score, invalidating the elements of the policy that could only be checked on the ground- Hilton did not accept a visit to their Mallorca hotel affecting a percentage of their validation, and RIU denied visits to any of their hotels. The field validation was conducted by three researchers who were thoroughly briefed on their task, and considerable triangulation prior to scoring took place to ensure internal consistency of assessment. Evidence was collected to justify the 
validation in each site and entered in to each company profile. To further strengthen the performance index public disputes were examined, i.e. where for example the hotel chain had been taken to court and lost the case. The consumer associations emphasised that the research team was only to look at corporate behaviour in the last five years. As a result this meant excluding resort development aspects from the criteria. Consequently the focus was largely on operational aspects. Results were presented to the consumer associations in November and the final report submitted in December, with the publication of articles in the consumer association magazines taking place in March 2011.

\section{Results}

We first present evidence for the six key themes identified above. The analysis draws initially on the ten international hotel groups' corporate social responsibility policies as documented in publicly available sources, responses to the surveys and internal information (table 3). We then move on to review how the field visits partly validated certain aspects of the corporate policies and procedures (table 4). This then sets the picture for the discussion of results against the backdrop of the CSR rankings based on validated disclosure (table 5).

Table 3. CSR voluntary public disclosure, survey and internal documents (out of 100\%)

\begin{tabular}{|c|c|c|c|c|c|c|c|c|}
\hline & 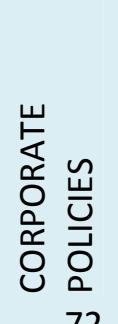 & 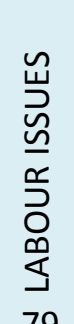 & 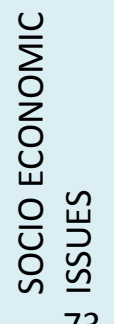 & 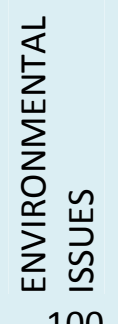 & 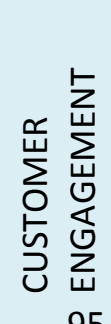 & 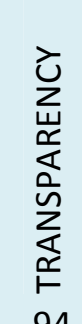 & 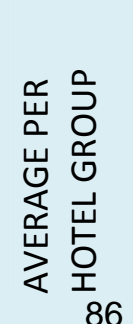 & Ranking \\
\hline ACCOR & 72 & 79 & 73 & 100 & 95 & 94 & 86 & 10 \\
\hline BARCELÓ & 43 & 50 & 45 & 70 & 62 & 82 & 59 & 7으 \\
\hline CARLSON & 56 & 79 & 76 & 74 & 82 & 65 & 72 & 5은 \\
\hline HILTON & 53 & 35 & 46 & 82 & 35 & 68 & 53 & 80 \\
\hline IBEROSTAR & 21 & 3 & 47 & 50 & 50 & 61 & 39 & 9o \\
\hline INTERCONTINENTAL & 59 & 82 & 77 & 91 & 66 & 96 & 79 & 20 \\
\hline MARRIOTT & 50 & 65 & 83 & 98 & 81 & 96 & 79 & 3응 \\
\hline RIU & 0 & 0 & 18 & 70 & 29 & 12 & 22 & 10 은 \\
\hline SOL MELIÁ & 61 & 68 & 83 & 94 & 59 & 100 & 78 & 40 \\
\hline STARWOOD & 54 & 79 & 50 & 95 & 56 & 78 & 69 & 60 \\
\hline Average per Section & 47 & 54 & 60 & 82 & 62 & 75 & 64 & \\
\hline
\end{tabular}

Source: authors 
Corporate Policies showed endorsement of international conventions that did however not translate into evidence at the individual hotel level. Most hotel groups now have a CSR nominee in each hotel, these are usually either the chief engineer or the general manager who take CSR on as an additional task. There was little evidence that this was a substantial part of their roles, judged either on the basis of job descriptions or in terms of their daily routines. Environmental training was present in most policies, although the precise meaning of a training plan varied considerably between hotels. Evidence of broader CSR training, specifically a focus on the socio-economic impacts of the organisation, was extremely limited. ECPAT protection for children from sexual exploitation was an exception in this regard. Management systems data were collected only for environmental aspects of the business' operation and linked mainly to building management systems. Even these data were of variable quality- in some of the hotel groups there was no evidence that this information was used to inform decision-making. Overall, the policies were inward looking, with little acceptance of the wider impacts caused in the destination.

The Labour Issues theme reviewed the company's formal policy on working conditions. This included the International Labour Organisation's Core Convention, remuneration (minimum and living wages), discrimination, health and safety, overtime, disciplinary practices, family friendly working policies and job stability. Compliance with local legal requirements was the standard response when it came to assessing labour issues. There was little transparency in the limited published information available on HR issues. This together with the results of the survey and internal documentation show that fair employment practices are not integrated within CSR strategies.

Socio-economic Issues focused on sustainable supply chain management policies (local, fair trade, eco-labelled products). The analysis showed that the adoption of sustainability principles in practice resulted only in a tokenistic impact on purchasing policies. Measuring and managing social impacts at the destination was also limited- while only Marriott and Intercontinental have policies on monitoring loss of natural resources. As mentioned, most groups were signatories of ECPAT's code against child sexual exploitation, yet few have developed operating procedures to deal with it (Barceló was the exception). All groups had well established philanthropy programmes.

Environmental Issues covered in companies' policies dealt primarily with issues of energy and water management. Hilton Europe (not elsewhere) has a well documented programme with metrics (Bohdanowicz, Zientara and Novotna, 2011), similar to those in Accor, Marriott, Intercontinental, Sol Meliá and Starwood. The substantial savings that these groups are achieving through energy and water efficiency programmes are however not ring-fenced to flow into CSR budgets. Health and safety justifications tend to prevail whenever there is any perceived conflict between conspicuous consumption and safeguarding scarce resources (for example promoting the use of disposable plastic glasses near pools as glass should not be used, while dismissing the use of washable toughened plastic glasses). Solid waste management is being implemented primarily through local government pressure (but has not gone upstream, hotels are not asking their suppliers to reduce the packaging coming into their businesses). There is some evidence of water re-usage and liquid waste filtration but not 
widespread- these are experimental in newer buildings or in sites where grants were available. The policies to preserve biodiversity are poor (Accor, Carlson Europe and Intercontinental perform best here) but all companies fail on implementation. When carbon footprint monitoring occurs, it is an extension of the energy management policy, and the calculations are of in house emissions only, i.e. the do not include supply chains.

Customer Engagement comprised issues around accessibility, dietary provision and involvement of customers in sustainability programmes. Very little is done on accessibility beyond legal compliance. The same principle applies to dietary requirements. The need for celiac provision, for example, is dealt with by a buffet approach to food management and limited specific products available by prior order. The approach to engaging customers might best be summed up under the motto: "Do not disturb”. Even such basic issues as recycling, let alone more complex information about how to behave responsibly is largely avoided (the policies from Accor, Carlson Europe and Asia-Pacific, Intercontinental and Marriott go further than those of the other groups, although this does not of course guarantee compliance).

The Transparency issue was rated on the basis of cooperation with the survey (only Accor, Barceló, Carlson Europe and Sol Meliá responded by the deadline while others collaborated more reluctantly, after some further exhortation) and the quality of the CSR report- Carlson Europe, Intercontinental, Marriott, and Sol Meliá had Global Reporting Initiative-checked reports. While useful as a complementary tool to an external form of assurance, the GRI Check confirms the completeness and correctness of a report's content index and as such is not an external audit of what a company says it does.

\subsection{The disclosure-performance gap}

It is one thing to have a policy; it is another to adhere to it. For this reason, site visits were conducted that revealed the following. Site visits demonstrated some investment to meet sustainability requirements, some ritualised behaviour for the benefit of the visit, and some evidently inappropriate practices contradicting policies. Table 4 presents the percentage of the companies' policies and procedures that were invalidated through the hotel visits. The hotel group with the highest policy scores was also the most consistent in implementation, whereas the second and third in consistency of implementation (Barceló and Iberostar) had some of the poorest initial policy scores. Intercontinental and Marriott, with the second and third most comprehensive policies and internal systems, were the least consistent in implementation (RIU aside). Hilton would have fared considerably better had they not denied participation of one hotel. RIU data distort averages for they had no disclosure on some criteria, or in those where they had some policies these could not be checked on site as the group denied participation.

Table 4. The Disclosure-Performance gap (percentage of points lost) 


\begin{tabular}{|c|c|c|c|c|c|c|c|c|}
\hline & 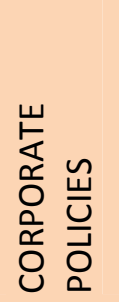 & 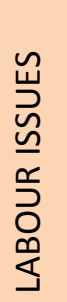 & 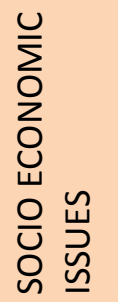 & 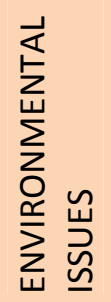 & 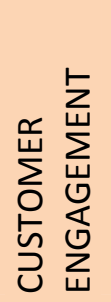 & 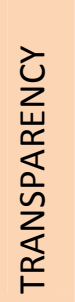 & 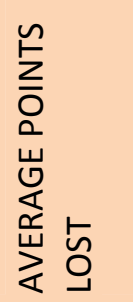 & Ranking \\
\hline ACCOR & 2 & 0 & 3 & 8 & 22 & 0 & 6 & 1응 \\
\hline BARCELÓ & 4 & 0 & 1 & 21 & 26 & 0 & 9 & 20 \\
\hline CARLSON & 10 & 2 & 10 & 11 & 34 & 0 & 11 & 50 \\
\hline HILTON & 10 & 23 & 14 & 35 & 38 & 0 & 20 & 60 \\
\hline IBEROSTAR & 7 & 13 & 23 & 25 & 21 & 0 & 15 & 3응 \\
\hline INTERCONTINENTAL & 13 & 0 & 14 & 37 & 42 & 0 & 18 & 80 \\
\hline MARRIOTT & 6 & 0 & 9 & 36 & 37 & 0 & 15 & 9음 \\
\hline RIU & 0 & 0 & 24 & 99 & 66 & 0 & 31 & 10 은 \\
\hline SOL MELIÁ & 4 & 2 & 26 & 25 & 23 & 0 & 13 & 7음 \\
\hline STARWOOD & 9 & 0 & 8 & 15 & 33 & 0 & 11 & 40 \\
\hline Average per section & 7 & 4 & 13 & 31 & 34 & 0 & 15 & \\
\hline
\end{tabular}

Source: authors

The greatest disclosure/ performance gaps were identified in the categories Environmental Issues and Customer Engagement. This is in part down to relative ease of assessment of these issues. To a degree this can also be attributed to the fact that companies had higher disclosure results in the first place, as well as more ambitious policies. In other words, there were more chances of not entirely fulfilling these policies given their exacting nature.

Most Labour Issues policies were driven by compliance with legislation. It is not surprising that the disclosure/performance gap was therefore small, and any additional sustainability practice such as contracting staff with difficulties of accessing work was anecdotal and could not be attributed to the company policy but was circumstantial or the result of government incentives. In Socio-Economic Issues, sustainability purchasing practices regularly fell below the stated policy’ claims.

It is worth remembering that several Corporate Policy and all Transparency indicators were checked with documentary evidence from group headquarters and not in the field, hence lower disclosure/ performance gaps for these items prevailed. The Corporate Policy indicators with disclosure/ performance gaps related to the provision of staff training in social sustainability, and maintaining social sustainability systems (despite having achieved already poor disclosure scores, performance was worse). The equivalent training and systems for environmental aspects was more consistent with corporate policies.

While during most visits we saw policies not being entirely fulfilled, there was also evidence of CSR practices that exceeded policy requirements. Individual hotel practices that went beyond the corporate policy and metrics were captured less often, and mainly as case studies in the internal organisation's magazines or on notice boards on the intranet. The presentation of case studies in the corporate social reports, evident in earlier CSR posturing (Laufer, 2003), was less common- the disclosure/ performance gap was $15 \%$, or $13 \%$ if we remove 
RIU. In this sense it could be argued that many of the policies were only partly representative of individual hotel practices, and in some places hotel groups were conservative in choosing to make public data that could be open to scrutiny.

\section{Discussion}

Table 5 brings together the evidence from the previous two tables into a single weighted ranking of CSR practices that forms the basis of the following discussion.

Table 5. CSR rankings- disclosure weighted with performance (out of 100\%)

\begin{tabular}{|c|c|c|c|c|c|c|c|c|}
\hline ACCOR & 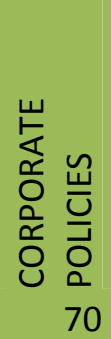 & 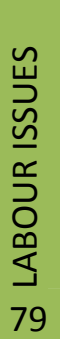 & 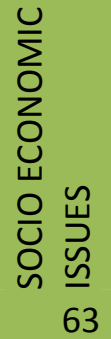 & 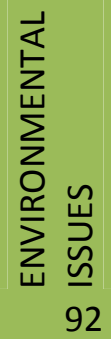 & 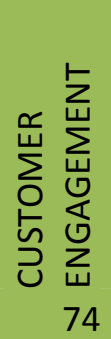 & 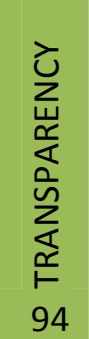 & 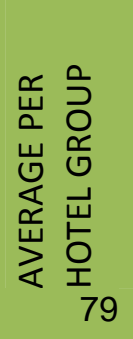 & $\begin{array}{c}\text { Ranking } \\
10\end{array}$ \\
\hline BARCELÓ & 41 & 50 & 44 & 55 & 46 & 82 & 53 & 70 \\
\hline CARLSON & 50 & 77 & 68 & 65 & 54 & 65 & 63 & 50 \\
\hline HILTON & 48 & 27 & 39 & 53 & 22 & 68 & 43 & 80 \\
\hline IBEROSTAR & 20 & 3 & 36 & 38 & 40 & 61 & 33 & 9o \\
\hline INTERCONTINENTAL & 52 & 82 & 66 & 57 & 39 & 96 & 65 & 40 \\
\hline MARRIOTT & 47 & 65 & 75 & 63 & 51 & 96 & 66 & 3은 \\
\hline RIU & 0 & 0 & 14 & 1 & 10 & 12 & 6 & 10 은 \\
\hline SOL MELIÁ & 58 & 67 & 62 & 71 & 46 & 100 & 67 & 2o \\
\hline STARWOOD & 49 & 79 & 46 & 81 & 37 & 78 & 62 & 60 \\
\hline Average per section & 43 & 53 & 51 & 58 & 42 & 75 & 75 & \\
\hline
\end{tabular}

Source: authors

As Accor came out on top in CSR policy as well as performance and disclosure it also ranks first in the overall assessment of companies' CSR performance. Sol Meliá who come in on second place overall scored poorly on the disclosure-performance gap (Table 4). Marriot who scored third overall on CSR policy scored a poor ninth in terms of the disclosure-performance gap and yet still achieved an overall position of third in the ranking. Does this mean that the disclosure-performance gap should have been more heavily weighted, for example? Of course, there is no unequivocal answer to this question. We recognise that the measurement of social phenomena is fraught with difficulties and yet the data and their analysis bring home the point that relying solely on company claims in an assessment of CSR performance is highly suspect. Transparency in reporting and external assessment raises the bar in terms of ensuring the disclosure-performance gap is reduced. Thus, while other studies have provided useful data on tourism companies' CSR claims (Bohdanowicz and Zientara, 2009;Holcomb, et al., 2007), this study illustrates that strong claims are not necessarily indicative of strong performance. 
Terrachoice (2009) reports that the most commonplace manifestation of greenwashing are hidden tradeoffs in environmental claims- the sin of focusing on a single green attribute which is not necessarily the most significant for the product and that deflects attention from other issues. There is a sense of organisational hypocrisy when the simplest eco-efficiency tasks can be dressed up as "save the planet" campaigns (Laufer, 2003) as found in hotel groups that went no further than energy and water management with short payback periods on initial investments (Hawkins and Bohdanowicz, 2011). In this regard we can say we found greenwashing in the emphasis placed on ecosavings-related environmental performance criteria, primarily energy and water management, while other more complex criteria such as biodiversity conservation are generally ignored or at best taking second stage. Nonetheless, the situation does appear to have improved since Holcomb et al. (2007) conducted their study when almost the entire CSR emphasis was on philanthropy, and environmental management played a very small role in CSR communications.

Previous evidence that firms with better environmental performance have better disclosure (Clarkson, et al., 2008) could only be partly validated although it seems reasonable to assume that a positive relationship exists. Thus, according to Lyon and Maxwell (2011), greener firms are more likely to fully disclose in situations of increased threat of punishment from greenwashing if they have to date a largely positive record in this respect. This was the case in particular for Marriott and Sol Meliá, both high performers in the rankings who fully engaged in disclosing internally confidential information (Marriott provided near 100 internal documents of substantial value as evidence for CSR policy implementation). Greener firms albeit with a mixed record (high performers in some areas but with negative performance in others) are likely to clam up and avoid public disclosure (greenhushing). This is in accordance with Lyon and Maxwell's (2011) view of greenwashing that suggests that activist pressure deters greenwash but also encourages greenhushing for fear of becoming a target by sticking your head above the parapet. Keeping a low profile minimises the risk of being targeted for closer scrutiny. The clear assumption behind Lyon and Maxwell's view is that greenwash will be punished so it is better to greenhush as this runs a lower risk of scrutiny.

On the issue of greenhushing it is worth noting that when RIU were approached to participate in the study they asked not to be included in the sample on the grounds that, due to it not being a listed company, they did not have a CSR report, and furthermore, did not feel they had sufficient time to engage with the project. The hotel group continued to decline any participation over six months, in the knowledge that this would place them at the bottom of the rankings and that publicly available information would still be included for analysis. RIU's behaviour may be termed rational on the basis of Lyon and Maxwell's proposition if RIU's actual CSR performance is weak. Low sustainability performance would mean any disclosure would still place them at the bottom of the ranking; therefore it makes sense to simply not disclose any information. This does not mean however that poor CSR performance will inevitably lead to non-disclosure. Barceló is a case in point. Its behaviour corresponds to the "informed browns" profile (Lyon and Maxwell, 2011), by collaborating with the research despite their low performance to gain points through transparency: "it gains a lot from trumpeting a success, and loses little by withholding information about a failure 
(because it is already expected to fail)" (2011:21). Ultimately, whether to disclose or not to disclose is a judgement call as to how firms believe consumers will respond. Evidence in this area is still scant.

We found evidence that large firms disclose more, but there is no conclusive evidence of whether this is based on the fact that this has lower information production costs (Clarkson, et al., 2008), or that they feel greater legitimization pressure to do so (Hawkins and Bohdanowicz, 2011). Size has to a certain extent been a constraint, not an advantage, in corporate reporting- Carlson sent separate responses for their three divisions (Europe, Americas and Asia-Pacific) with considerably different policies, and Hilton Europe is ahead of the rest of the Hilton Group. When visiting the hotels it was apparent that many locally relevant practices could only be reported up to group level, but not become group policy, for not being transferable- to a certain extent group policies tend to go back to the lowest common denominator. There is furthermore evidence that firms with greater capital expenditures disclose more (but firms with newer production plant do not disclose more, against expectations) (Clarkson, et al., 2008)- in our study this would be true of hotel groups that own most of their branded hotels, whereas franchise hotels have substantially poorer practices, an issue that deserves further research.

Finally, Legitimacy Theory, which associates extent of disclosure with level of threat to a firm's social legitimacy (Patten, 2002), would explain some of the attempts for soft disclosure (e.g. Iberostar, Barceló) as self serving disclosures to appease stakeholders by providing some form of data. It would be erroneous to believe however that all soft disclosure is simply posturing. For example, Iberostar's EMAS certification of most of its Spanish hotels (30\% of its hotel plant) may be judged more than hiding behind a façade. In Iberostar's case the weakness lies in the lack of company-wide policies or systems, the lack of coordinated structure, and being limited to environmental aspects only.

\section{Conclusions}

The picture of CSR performance is a mixed one. While on the whole discrepancies between policy and performance exist, in some cases considerable discrepancies, in others CSR activities in fact exceeded policy requirements. Non-adherence to policy does not automatically therefore mean weaker CSR performance at the level of the individual hotel, it means not following company standards. We would argue that having been able to assess the implementation of policy on the ground has added a valuable extension to previous work in the field. While content analyses of hotel chains' CSR claims have been undertaken (Bohdanowicz and Zientara, 2009;Holcomb, et al., 2007), this study has shown just how important external audits are. Without these audits, companies are free to engage in greenwashing and greenhushing, and, on the basis of this study's data, readily do. KPMG's (2008) survey of CSR reporting has indicated that large corporations are increasingly willing to provide evidence for the claims they make in their CSR policy commitments, and indeed undergo external audits. The trend for increased CSR reporting is clear. Hotel chains will not be able to extricate themselves from this trend and the justification of the unwillingness of 
some chains to participate in this study on the grounds that CSR is a voluntary activity rings hollow.

Moreover, the study has provided evidence that strength of CSR engagement varies by theme. There was a strong emphasis on environmental issues, most notably energy and water management. These are also areas where immediate cost savings can be gained. This issue aside, many CSR policies simply reiterated legal requirements. On the basis of Carroll's (1979) taxonomy of reasons for CSR engagement, hotel chains' largely avoid anything that does not benefit the business immediately. As such they adhere to Friedman's (1970) view of the responsibilities of the firm which is a responsibility to the business (its owners) first and foremost, albeit within legal requirements of course. The exception here are philanthropic gestures such as corporate donations although here too benefits to the bottom line are created if these acts of giving are widely publicised leading to a strengthening of brand image and reputation. Another important insight from the study is that the focus on CSR was largely inward looking. There was little regard for impacts on the destination or on establishing sustainable supply chains. Ironically, hotels being physically tied to the destination are more reliant on its wellbeing than many other sub-sectors of the tourism industry (UNWTO, UNEP and WMO, 2008).

More work needs to be done on creating robust indices and rankings, and yet the difficulties in assessing compliance with policy should not be used as an excuse to avoid comparisons of companies within the same sector. There were some very clear differences between hotel chains' claims, engagement and performance. This is indicative of a lack of maturity in embedding CSR within corporations. Some hotel chains still have much catching up to do if they want to be on a par with the leading firms. If the pressure on businesses to take responsibility for their wider impacts on society continues to grow, then the catch-up game becomes all the more critical. 


\section{References}

Bebbington, J., Gray, R. and Owen, D. (1999). Seeing the wood for the trees. Accounting, Auditing and Accountability Journal 1247-51.

Bendell, J. (2004). Barricades and Boardrooms. A Contemporary History of the Corporate Accountability Movement. In "Technology, Business and Society Programme Paper Number 13", pp. 72. United Nations Research Institute for Social Development.

Bohdanowicz, P. and Zientara, P. (2009). Hotel companies' contribution to improving the quality of life of local communities and the well-being of their employees. Tourism and Hospitality Research, 9(2), 147-158.

Bohdanowicz, P., Zientara, P. and Novotna, E. (2011). International hotel chains and environmental protection: an analysis of Hilton's we care! programme (Europe, 20062008). Journal of Sustainable Tourism, 19(forthcoming).

Boiral, O. (2007). Corporate Greening Through ISO14001: A Rational Myth? Organization Science, 18(1), 127-146.

Bonilla-Priego, M.J. and Avilés-Palacios, C. (2008). Analysis of environmental statements issued by Spanish EMAS certified hotels Cornell Hospitality Quarterly, 49(4), 381394.

Bonilla-Priego, M.J., Najera, J.J. and Font, X. (2011). Environmental management decisionmaking in certified hotels Journal of Sustainable Tourism, 19(3), 361-382.

Carroll, A. (1979). A three-dimensional conceptual model of corporate social performance. Academy of Management Review, 4, 497-505.

Carroll, A. (1999). Corporate Social Responsibility: Evolution of a Definitional Construct. Business \& Society, 38(3), 268-295.

Chatterji, A.K., Levine, D.I. and Toffel, M.W. (2009). How well do social ratings actually measure corporate social responsibility? Journal of Economics \& Management Strategy, 18(1), 125-169.

Clarkson, P.M., Li, Y., Richardson, G.D. and Vasvari, F.P. (2008). Revisiting the relation between environmental performance and environmental disclosure: An empirical analysis. Accounting, Organizations and Society, 33(4-5), 303-327.

Frankental, P. (2001). Corporate social responsibility: a PR invention? Corporate Communication: An International Journal, 6(1), 18-23.

Friedman, M. (1970). The Social Responsibility of Business is to Increase its Profits. In "The New York Times Magazine", New York.

Hawkins, R. and Bohdanowicz, P. (2011). Responsible hospitality: theory and practice,London: Goodfellow

Healy, P.M. and Palepu, K.G. (2001). Information asymmetry, corporate disclosure, and the capital markets: A review of the empirical disclosure literature* 1 . Journal of Accounting and Economics, 31(1-3), 405-440.

Henderson, J. (2007). Corporate social responsibility and tourism: Hotel companies in Phuket, Thailand, after the Indian Ocean tsunami International Journal of Hospitality Management, 26(1), 228-239.

Hess, D. (2008). The Three Pillars of Corporate Social Reporting As New Governance Regulation: Disclosure, Diablogue, and Development. Business Ethics Quarterly, 18(4), 447-482.

Holcomb, J.L., Upchurch, R.S. and Okumus, F. (2007). Corporate social responsibility: what are top hotel companies reporting? International journal of contemporary hospitality management, 19(6), 461-475.

Kaptein, M. (2007). Ethical Guidelines for Compiling Corporate Social Reports. Journal of Corporate Citizenship, Autumn 2007(27), 71-90. 
KPMG International (2008). KPMG International Survey of Corporate Responsibility Reporting 2008. KPMG.

Lang, M. and Lundholm, R. (1993). Cross-sectional determinants of analyst ratings of corporate disclosures. Journal of Accounting Research, 31(2), 246-271.

Laufer, W. (2003). Social Accountability and Corporate Greenwashing. Journal of Busines Ethics, 43253-261.

Lyon, T.P. and Maxwell, J.W. (2011). Greenwash: corporate environmental disclosure under threat of audit. Journal of Economics \& Management Strategy, 20(1), 3-41.

Morhardt, J.E. (2010). Corporate social responsibility and sustainability reporting on the Internet. Business strategy and the environment, 19(7), 436-452.

Morimoto, R., Ash, J. and Hope, C. (2005). Corporate Social Responsibility Audit: From Theory to Practice. Journal of Business Ethics, 62(4), 315-325.

Patten, D. (2002). The relation between envrionmental performance and environmental disclosure: a research note. Accounting, Organizations and Society, 27(8), 763-773.

Terrachoice (2009). The seven sins of greenwashing: environmental claims in consumer markets. Summary Report: North America.

Unerman, J. (2000). Reflections on quantification in corporate social reporting content analysis. Accounting Auditing and Accountability Journal, 13(5), 667-680.

UNWTO, UNEP and WMO (2008). Climate change and tourism: responding to the challenges. UNWTO, Madrid.

Wiseman, J. (1982). An evaluation of environmental disclosures made in corporate annual reports* 1. Accounting, Organizations and Society, 7(1), 53-63.

Wood, D. (2010). Measuring Corporate Social Performance: A Review. International Journal of Management Reviews, 12(1), 50-84. 